\title{
NETWORK CAPITAL DEPENDENT PATH-DEPENDENCY ${ }^{1}$
}

\author{
ENDRE SIK ${ }^{2}$
}

\begin{abstract}
Path dependency is created and maintained by three intertwined influences of network capital; that is, the inertia of the networks, the culture which defines the proper use of network capital, and the way such network capital fits into the local and global institutional setting. Following a brief introduction of the terms network capital and path dependency, I develop an extremely simplified dual typology to differentiate between network-sensitive and network-insensitive societies. These two extremes of a continuum characterize societies in which either everyday life is under the total domination of network capital or where networks are auxiliary resources to be used in rare and special situations. I will show how both communism and post-communism have been a fertile institutional setting for the emergence of network-sensitivity and how network capital under such conditions become so powerful that it shapes other institutions to its needs. In the last section I shall argue that the mechanisms I described in a networksensitive institutional setting are present in a network-insensitive one as well, and that there are signs that globalization increases the level of network-sensitivity all over the world.
\end{abstract}

KEYwORDs path dependency, network capital, embeddedness

\footnotetext{
1 The paper is the modified version of a working paper first presented at the conference "Recomposing Eastern Europe? Inner Frontiers: Real and Imagined", Bucharest, October 2000.

2 Endre Sik is a professor of sociology at ELTE TáTK and TÁRKI; e-mail: sik@tarki.hu.
} 
"It sounds like a joke, but maybe it's true: those who have friends are less prone to catch colds, and if they actually do, then they get rid of them more easily."

(Gombár 1998) $)^{3}$

"I literally expose myself to lethal danger by keeping myself free of corruption, for I've been repeatedly threatened by strangers ... trying to remain honest is the most dangerous thing you can do in Hungary. And you won't be accepted in "business circles" either...

(a former business manager of an insurance company)

To start with the final claim: path dependency is (partly, but to a great and perhaps increasing extent) created and maintained by three intertwined influences of network capital; that is, the inertia of the networks, the culture defining the proper use of network capital, and the way such network capital fits into the local and global institutional setting. In this paper I shall examine, on the one hand, how network capital influences economic and political action - thereby justifying the saying in the first quotation, and on the other - accepting the analysis of the situation advocated by the second quotation how this collective value turns into a collective "deficiency".

As to the structure of the paper, following a brief introduction of the terms network capital and path dependency, I develop an extremely simplified dual typology to differentiate between network-sensitive and network-insensitive societies. Such extremes obviously can be conceptualized only as ideal types. These two extremes of a continuum characterize societies in which either everyday life is under the total domination of network capital or where networks are auxiliary resources to be used in rare and special situations. I will show how both communism and post-communism have been a fertile institutional setting for the emergence (not from nothing, though!) of network-sensitivity, and how network capital, under such conditions, has become so powerful that it shapes other institutions to its needs. In the last section, however, I shall argue that the mechanisms I described in a network-sensitive institutional setting are present in a network-insensitive one as well, and that there are signs that globalization increases the level of network-sensitivity all over the world.

A point of departure of the analysis is the assumption that post-communist societies are network-sensitive. The second assumption is that the networksensitivity of these cultures remained intact during regime changes, and

3 A recent book (despite methodological weaknesses) made this joke known worldwide in a new discovery of network analysis (Christakis - Fowler 2009). 
it is not only capable of reproducing itself, but is strong enough to create such a path which offers a fertile institutional environment for thriving. In other words: the network-sensitive culture of post-communist societies not only changes very slowly ${ }^{4}$, and therefore slows down the changes of the institutional setting, but actively shapes the process of transformation in ways beneficial for those actors who can politically and economically gain from these network-sensitive elements.

To sum up, if it is true that the inertia of network-sensitivity is high because of the structural causes mentioned above, then - unless the demand for network capital suddenly drops (a perfect market and/or a smoothly operating state emerge) and/or the constraints of using network capital thoroughly increase (a totalitarian state starts punishing the utilization of network capital with the death penalty ${ }^{5}$ ) - I assume that the importance of network capital will also survive.

If we accept that Hungary is a network-sensitive society and that the "Western" world surrounding it is network-insensitive, then the following analysis can be perceived as a natural experiment presenting the meeting of a network-sensitive path with a network-insensitive global world. Or, to put it in the language of path-dependency: in this essay, I endeavor to analyze what happens in a society progressing on a network-sensitive path when it comes to cross a network-insensitive path (or more precisely a busy highway). A trivial hypothesis is that if the Hungarian and global paths meet, the former will adapt to the latter (and not the other way round); however, the "Hungarian path" would not totally lose its own features, and perhaps, around the junction (just like when a sewage canal enters a rather dirty river), the global highway may show some degree of change as well.

\footnotetext{
4 Etzioni (1991) refers to the high inertia of transition as an outcome of the friction of change. He argues that this slows down cultural changes (much more than those induced by political or economic ones). Or as Dahrendorf (1990) has stated, it takes six months for constitutional reform, six years for full economic transition, and 60 years for major changes in the value system.

5 On the one hand, as barter between households becomes superfluous with an increase in general wealth (but never for the entire society), bribing (meant to overcome scarcity) can be reduced (but never disappears) in a well-developing market economy. On the other hand, the conscious destruction of network during the acute period of Stalinism (cf. the scattering and dismantling of choirs (both of churches and trade unions), the peasant economy, aristocratic extended family structures and generally speaking, any social and economic activity based on private networks, etc.) was not successful either.
} 


\section{NETWORK CAPITAL}

The term network capital derives from social capital. In the mid-1990s I decided to use this term (Sik 1994a) because I realized that the notion "social" in the social capital definition is a dangerously bad metaphor 6 . A Putnamian mix of such diverse phenomena as network, trust, civic participation, and solidarity unavoidably makes the term theoretically confusing and empirically useless - even more so due to its dichotomous nature (social versus nonsocial cannot be more than a bad metaphor because if we classify financial, human, physical and symbolic capital as non-social we commit the greatest sin a social scientist can; that is, we declare various forms of capital as being non-social, and by this we ignore all that Simmel wrote on money, Polanyi on market and redistribution, Granovetter on embeddedness, and Bourdieu on reconversion (let alone the intrinsically social nature of human and physical capital which even economists admit to)).

In regard to the notion of "capital" in the term social capital, I take it seriously only when the networks (which are not necessarily developed as a form of capital but emerge as "natural" by-products of our everyday life) under certain conditions, are converted into profit-oriented capital and have capital-like functions ${ }^{7}$; that is, Ego invests in his/her networks with the intention of making a profit at a later point in time ${ }^{8}$. It is true that networks have certain characteristics which should be taken into consideration when one applies the capital concept ${ }^{9}$, but these specialties do not question the fact that network capital is indeed a form of capita ${ }^{10}$.

6 For a detailed criticism of the social capital concept, see Sik 2006.

7 Following the opposite of the usual arguments why, for example, money is capital. I argue that money can be used as non-capital (it could be used for charity), knowledge in not used as human capital (learning the history of art could be a source of self-esteem or happiness), and physical capital (e.g., a taxi cab) can be used by the driver as a means of leisure.

8 Especially in high risk/high profit situations, conscious investment in networks might occur (such as the case with migration, major corruption transactions, and mutual aid in self-help building). But even when networks are not intentionally built as capital networks, they can help the owner to make a profit (either by decreasing the risk of being caught or increasing the efficiency of the use of other forms of capital, etc.).

9 Such as being embedded in face-to-face networks, the reconversion of it is often difficult, the inertia of its use is high because the investment involves other actors as well, and its ownership is shared with others, etc.

10 And a substantive analysis of money, knowledge, or various goods as capital shows that these also have certain characteristics which limit their use as capital. 


\section{ON PATH DEPENDENCY}

The classic work on path dependency demonstrates how the currently dominant version of the typewriter keyboard became dominant (without being the most effective) due to the high inertia of early investment, human capital development, brand name, etc. These interrelated factors created a "lock in" situation in which this keyboard structure was destined for success to the extent that, since then, it has survived every technical transformation; and even today the standard English computer keyboard has the same structure though there are no technical reasons for it whatsoever (David 1985).

According to Arthur (1988), path dependency is caused by positive feedback processes such as:

- for latecomers it is difficult (or expensive) to compete with the first investor, since by the time rivals enter the market, the first investor in the game has already produced large quantities, i.e. harvested the benefits of economics of scale, which means that they produce at a lower cost per unit;

- those who start earlier have acquired more experience in the fields of production and marketing and thus can increase their advantage by improving the quality of the product by reducing the costs of production, and by working with the customer even more;

- while those who started earlier are in the position of having well-tested, trusting relations with those working for them and with their retailers; such relations are costly and time-consuming for those arriving later to build;

- those who introduced the new product have the competitive advantage of being first to get the brand name, which gives them the reputation and prestige of being closely linked to the trade-mark ${ }^{11}$, while such a reputation can only be garnered by a latecomer with heavy investments in advertising, especially if specialized institutions such as advertising or market research have begun developing it.

Path-dependency theory also posits that these positive feedbacks do not necessarily result in development or improvement. North (1990) uses the model of path-dependency to explain why there are so many different human societies despite the advent of globalization, and why it is that badly functioning economies do not collapse.

North's definition of path dependency put emphasis on the role of chance

11 The extreme example of this is when the trademark of a product establishes itself as the actual name of a given product (e.g. Kleenex, Xerox, Hoover, Nescafe). 
as well: "(Path dependency is)... the consequence of small events and chance circumstances (which) determine solutions that, once prevail, lead to a particular path" (North 1990: 94). Chance events can launch processes which remain valid for a long time. Mutatis mutandis, chance events that nobody remembers may very well stand at the origin of decision chains leading to paths we perceive today as being the inevitable course of development.

As far as explanations of post-communist changes are concerned, the theory of path-dependency has been mainly reduced to repeating the commonplace according to which "history counts". Stark (1995), however, convincingly shows that the different privatization process in the course of post-communism are path-dependent adjustments to the available building material (brickolage) that can be harvested from the debris of country-specific communisms, and are reused in the course of building capitalism (even if its quality is questionable).

While the direction of the path is indeed decisive in understanding the social consequences of the transformation process, however, culture (and within it, network capital), as materials to be used in building a particular path, influence the features of the newly built path, and these features increase or lower the costs of transport, which in turn influence the value of that path as compared to other paths: there is more traffic on a better path.

The effect of culture is manifested in the form of traffic regulations (the way traffic is regulated and how such regulations are enforced), in people's expected behavior towards fellow drivers or the police, but also the number of roadside petrol stations, the density and availability of roadside rest houses, etc. Investment in network capital increases the inertia of existing cultural patterns (e.g., openness to corruption, favoritism, nepotism, attitudes to rules (to obey or avoid them) and reinforces interest in network-building and maintenance and trains the population in network-sensitiveness etiquette.

\section{DIGRESSION: HOW NETWORK CAPITAL ORIGINATES PATH-DEPENDENCY}

The coming about of French impressionism is a good example of the reciprocally reinforcing effect of a chance event, a network-sensitive subculture, and some other forces to create a high-inertia path by "discovering" network capital.

The starting point of the story is the chance event in which Napoleon III responded to the complaints of the painters who were rejected by the jury at the annual Salon des Beaux Arts (the official exhibition of the Academy of 
Fine Arts) in an entirely unexpected way, declaring that he himself wanted to see the rejected paintings. According to an art historian (Wilensky 1963), the reason behind the emperor's strange decision was that he wanted to humiliate the person who had organized the jury. The emperor peeped at the paintings and did not like them.

But the story did not end there; gossip, rumor, and the media ${ }^{12}$ made the rejected painters visible to the public, some critics, and potential collectorsinvestors. The painters found themselves thrown into a group and grasped this opportunity to retain this group-based inertia, and their reputation started to increase. Thus the Salon des Refusés, where Manet and Pissaro were exhibited, and Monet, Renoir, Cézanne, Bazille, and Sisley turned up as visitors which formed the basis of their avante-garde group. The nightlife in Paris at that time featured two aspects - cafés - and young, poor, hungry, ambitious artists - all fertile soil for the emergence of a network-sensitive subculture.

The future impressionist painters were generally bachelors and bursting with ambition and testosterone, so they met regularly at night in cafés where they shared drinks, in addition to sharing paint, women, ideas, and patrons and atelier. This small group sucked in anybody who showed some inclination to solidarity and could prove themselves a worthy part of the group. Together they were strong enough to survive their lack of success at the beginning to build up a network providing paint, food, and faith to its neediest members who paid for these services with their - then still worthless - canvasses ${ }^{13}$.

Those who did not turned up at the right time, and at the right places (they frequented other cafés, the ateliers of successful contemporaries, or the receptions of well-to-do Parisian friends) - as gifted and enthusiastic as they might have been - could not become part of the Impressionists' group, and benefit from the advantages of belonging to it. ${ }^{14}$

Friendly patrons, gallery-owners, and art dealers (and their descendants), disposed to good intuition, later acquired fortunes because they invested well

12 It was Zola in the first place who made angry attacks against the academy and widely publicised the cause of the rejected artists.

13 The fact that Zola, who provided them with publicity, became a peripheral member of the group was of course only an advantage. This created around them the aura of the bohemian (derived from the imagined life of Gypsies in eastern Czechia which was supposed to be independent, happy, adventurous, and free) which was mixed of being a promised sign of talent, and attracted rich patrons and investors to the group.

14 Ruskin, the influential English art historian, often travelled to Paris at the appropriate time (the 1860's), but lived in a small and quiet hotel, and did not frequent cafés. He never met the future Impressionists, and therefore does not mention them in his correspondence, his lectures, or books. 
at the beginning of the path-dependent process (often unintentionally, and simply because they wanted to help their poor and somewhat scorned clients, or out of helplessness, because they did not see any other way of recovering the credit they had granted). Later purchasers (or those buying paintings from them) of course made less profit, as the price of the pictures inflated exponentially from the moment the Impressionists became famous.

This network-sensitive path-dependency was not interrupted by the fading of Impressionism; it still exists today through:

- cultural institutions that were not in the picture originally, such as the image-industry (and the immense tourist sector built on it) of the bohemian universe of Paris ("the cultural capital of the world"),

- a new idea which started with (and in some early cases was the direct continuation of) Impressionists or were created by copying their practice (Pointillists, Neo-Impressionists, Symbolists, Fauves, Les Nabis, Dada, and the Surrealists in France and since then various artist groups around the world),

- an innovative market behavior according to which it is worthwhile to invest in the paintings of young, still unknown artists, to set up the system of small galleries and specialized show-rooms, and to discover and "produce" young artists.

\section{EVERYDAY LIFE IN A NETWORK-SENSITIVE SOCIETY}

To illustrate for the reader from a network-insensitive society what it is like living in a network-sensitive society, I attach a Greek snapshot and four examples:

"Greek society functions almost exclusively through personal networks. If two individuals come to an agreement, then they keep to it. ... In Greece, the enforcing role of reciprocity is still stronger than that of western-type contract-based engagements. For that matter, Greek people try to solve most of their affairs among themselves ...Law and Regulations are not considered to be the abstract materialization of civic equality and liberty, but rather materialized obstacles everybody should circumvent by all means if they want to reach their objectives."

(Fokasz 1999)

In more general terms, in a network-sensitive society:

- when a household runs out of salt, when a domestic appliance shows the first uncertain sings of having problems, when we are seeking auxiliary 
income or a bargain price, when we want cheap credit, or when we don't exactly know some legal regulation, our first thought will not be to find the next shop, the nearest service centre, bank, or lawyer but rather to find "the right person" who is naturally and instinctively somebody we know personally or somebody recommended by somebody we know personally;

- when we want to get something done, the question is not whether the official in charge can be bribed, whether giving a tip is appropriate or necessary, but rather what amount should be given and what version of the limited and widely known forms of etiquettes for the transfer might be. ${ }^{15}$ If the wording is properly chosen, the body language of an invitation to corruption is immediately and automatically identified as such. Moreover, "between us", we not only remain free of any sense of shame as far as corruption is concerned, but we often even boast about our skill in practicing it;

- we automatically link somebody's success to Ego's good network. ${ }^{16}$ We identify all strangers showing up in our social neighborhood (in our "circles") according to "whom they know". Similarly, if we find ourselves in "strange waters", we mostly lead the conversation to describing whom we met, when, and what we did together: we permanently keep ourselves ready to evaluate, take stock, and if necessary, mobilize the information we have related to the network capital.

Living in such a world implies that "everybody" knows that:

- to be part of networks is crucial; consequently investing into network capital is profitable (the principle of profit);

- everybody else does the same, so investing into network capital is obligatory (principle of community);

- to do so is "natural" and therefore easy (principle of culture).

Of course network-capital plays important roles in network-insensitive societies as well. The significant difference is, however, that these roles are always only

15 The Russian society according to Ledeneva (1998), for instance, has irremediably and irrevocably become network-sensitive. In this approach, distrustfulness towards the State, reinforced by centuries of authoritarianism, made everyday life in Russia very networksensitive.

16 According to Rose and Haerpfer (1992), disposing of network within political circles and abroad is, in the eyes of the majority of the Bulgarian, Czech, Polish, and Slovakian populations, a much better source of success than intelligence, work, or dishonesty. 
auxiliary. People in network-insensitive societies also conclude contracts on the basis of verbal agreements, must deal with corruption, and also help each other, as neighbors and family members do, in such cultures. The difference is that when compared to network-sensitive cultures, people in network-insensitive cultures, will think of a market solution before resorting to appeals based on personal connections. Corruption is risked only as a last resort (in order to secure a deal in which a very big profit is implied), and it is done very sparingly and occasionally, for it involves a high risk of getting caught; and if you are, then apart from the legal consequences of your act, you must also reckon with being (at least temporarily) excommunicated (the reason why it is not really advisable to hint at readiness for corruption, even privately).

\section{DEPENDING ON NETWORKS IN COMMUNISM}

In the following examples, I shall demonstrate the network-sensitivity of Hungarian society before the change of regime, its structural origins, and its capacity for self-preservation.

The network-sensitivity of a communist society in general was a consequence of a number of strategies fighting against shortage - a structural feature of everyday life under communism. The system of barter-relationships was the best insurance against various forms of crisis in the course of production, be it a shortage of raw materials or of tools in factories (Héthy - Makó 1972), or the annual crisis situation brought about in all agricultural cooperatives with the poor conditions of harvesters, the lack of gas, and the lack of spare-parts (Czakó - Sik 1988). Consumption shortages could mainly be cured through bribing, tip giving, and/or barter, be the service or good a hospital bed, an entrance exam, a piece of meat, or durable consumer goods. ${ }^{17}$

The inertia of these networks was significantly increased if those interested in it were in the position of enforcing the conditions which perpetuated it. For example, the waitress who generates a tip or bribe by retaliating against customers who don't tip by serving awful coffee; the taxi driver who throws back the tip judged insufficient at the client; the policeman who creates their own bribe situation; the clerk who is interested in increasing the complexity of bureaucratic

\footnotetext{
17 There are numerous Russian examples (Berliner 1957; Ledeneva 1988; Mars - Altmann 1983 ) to illustrate these networks. Altmann (1990) as a case study describes a full-barter circle: import shoe - four kilos of illegally-slaughtered pig meat - first-class Aeroflot ticket car lent for an excursion (one day) - a rare book from a public library (borrowed, not stolen) - jumping the queue for an operation - a cup of instant coffee - bicycle service part - import shoe.
} 
rules, the bank employee who slows down the credit process. The tolerant and/ or subservient public attitude toward such behavior helped preserve corruptive relationships, and reinforced the anti-state basis of the network-sensitive culture.

Hearsay, gossip and "unofficial publicity" is a vital element of keeping anti-state values alive (Sampson n.d.). Such informal modes of conveying information functioned to embed themselves into the networks of private life; hearsay has thus become a network capital based system-specific phenomenon functioning as a defense mechanism guarding the private sphere, which is built on personal relationships allied against the official system where those not personally known may be unreliable or even dangerous. This threat and uncertainty (imagined or real, no one could ever know which is the more likely case) was a fertile soil upon which particularistic trust blossomed and generalized trust was inhibited.

Communism inevitably and strongly increased the network-sensitivity of business and political life (Lonkila 1999; Ledeneva 1998; Rose-Ackerman 2001). As a mechanism of survival, it forced the survival of ancient (if not "eternal”) forms of inter-household networks such as mutual aid, or balanced reciprocal exchanges as well (Sik 1988).

\section{DEPENDING ON NETWORKS IN POST-COMMUNISM}

I assume that network-sensitivity survives the transition, and moreover, creates an environment of institutional non-change. In other words, the transformation is path-dependent and is based on network capital; that is, the width, material, and paint on the path undergoes various visible transformations, while underneath it remains basically the same.

Data suggest that post-communist everyday life is network-sensitive. 76$90 \%$ of Bulgarians, Czechs, Slovaks, and Ukrainians assume that official matters are usually settled with network help, and 62-91\% think that gratitude for service should be rewarded with a small present (Miller et al. 1998). More than four fifths think that the elements of corruption are more widespread in post-communism than they were in communism (Rose - Haerpfer 1992). 66$71 \%$ of Russians can count on a loan and help from acquaintances and family members in case of an illness (Rose - Haerpfer 1992). Analyses unanimously show that since the change of regime, the part played by personal connections in the labor market has become more important (Clarke 2000; Yakubovich Kozina 2000).

The dominance of inter-household exchange has survived the change of regime in Hungary (Albert - Dávid 1998; Harcsa - Bocz 2001) as well 
as in Russia. Traditional family-centric network capital is still stronger in post-communist Hungary than in the West. (Angelusz - Tardos 1988, 1998) The same is true in Russia, where the number of people living in the same household is increasing, and all kinds of new household members (who are not part of the family in the narrow sense of the term) are appearing as costlowering manpower (O'Brian et al. 1996).

Post-communist political life is characterized by a number of phenomena that assumes that political actions should lean more on network capital than in network-insensitive circumstances. For example, since the political transition was unexpected and fast, the newly emerging parties did not have time to develop their cadres, and consequently were forced to do network-based recruitment through peer groups, friends, kin, etc. (Czakó - Sik 1995).

The continuity of network-sensitivity is also encouraged by the fact that trust in the new political powers is not greater than the confidence that was placed in the communist state ${ }^{18}$.

The strength of network-capital is on the rise in the economic sphere as well, in part since network-sensitive processes are on the rise all over the world (flexibilization, industrial districts, etc.), and in part because in addition to these processes there are transformation-specific elements which assume network-sensitivity, such as credit-starved petty entrepreneurs who strengthen their cooperation in times of crisis (Kuczi - Makó 1997, Sik 1994b).

In addition, the well-developed informal economy maintains a networksensitive institutional setting for many reasons, such as substituting for and defending against state regulation and legal guarantees, diminishing the large risk of transactions, speeding up the flow of information, providing trust, etc ${ }^{19}$. The uncertainty created by the change of regime (the weakness of the state, the quick rise in previously unknown phenomena (such as un- or under-employment, private ownership, taxation, or new banking techniques), impoverishment, or the instability of justice) increased the role played by network-capital in the functioning of the informal economy even more.

This process was encouraged and channeled by the decades-long experience of Hungarians having been socialized by the network-sensitive informal economy of communism. Obviously the private enterprises that

18 According to Mishler and Rose (2001), the average value of general trust in 1998 in ten formerly socialist countries (on a seven-grade scale, with seven being the maximum) was 4.39 - a value much higher than the average trust of state institutions (3.6).

19 Just as the Mafia, itself an organisation featuring high network-sensitiveness, may be regarded as a group specialising in the militant monopolisation of network capital. 
were established under communism relied on their network-sensitive coping techniques they were experienced in (such as tax and social insurance or cheating or smuggling) to reduce costs, and successfully used these techniques as a defensive mechanism in the last period of communism. The rationale of this practice was that, on the one hand, their market situation worsened (more competition from abroad and less solvent demand on behalf of the impoverished local economy), and on the other, the networks which were used in this process were often the only (human, cultural, and network) capital in abundance, and available without any further investment costs.

The new entrepreneurs (often being forced to go private to escape unemployment or impoverishment) needed network capital as well to learn the ways to get access to credit, clientele, etc., as well as to learn the same managing techniques their predecessors already knew, e.g., how to elude (or at least postpone and reduce the severity of) state control. This explains why small-entrepreneurs did not support the liberalization of the market (Gábor 1994), and why corruption (as referred to in the quotations in this paper) became a "matter of course" in business life:

"Networks become increasingly important. They start to be the only thing that matters...I go on until I find the connection I need. If money makes it, then I use money, if it's a favor, then I do that favor...Does corruption exist? That's not a question: it's either a sign of naivety or a pseudo-question...Everything and everyone has got a price. That's the truth."

(Tóth 1999: 148-159)

Pyramid schemes and direct or multi-level marketing schemes are networksensitive business procedures, since network-based recruitment is the alpha and omega of their functioning. The fact that these schemes (or scams) became so popular in Eastern Europe during the transition is a new argument for network capital dependent path-dependency. The popularity of these business practices was caused (apart from the desire to become rich fast; a desire rooted in poverty and hopelessness (cf. Magyari-Vincze - Feischmidt 1994) and no previous experience with this form of cheating) by the network-sensitivity of society.

Interlocking directorship and reciprocal participation in supervising and management boards are present in every market economy. However, their innovative forms (recombinant property, i.e. overlapping and intertwined ownership of state and private, and of several seemingly independent but in fact continuously sold and bought and re-bought assets) did not became very popular in Hungary. These innovative forms can be regarded as a type of network-sensitive management that became especially useful during the 
first phase of transformation (Stark 1996; Vedres 2007). The (temporary) success of this organizational mode created an extremely network-sensitive mode of ownership. This was partly a response to the need for know-how and investment, but transition-specific processes (such as privatization, special credit schemes, etc.) contributed to its usefulness as well. To be successful in this period required high-trust relations among partners with different backgrounds, and since speed was essential and the legal environment was uncertain (which made all transactions often dangerously close to illegal) an especially high level of trust was necessary.

It is obvious that privatization cannot be undertaken without network capital. Especially in the beginning when the value of state property was unknown (since there was no market which could have helped in valuing the stock). In this situation potential buyers had to have insiders who knew (or at least could guess) the value of assets, and who knew the bureaucrats who were in charge of selling these assets within an unstable system of rules. Since the state was interested in selling as fast as possible (being in a fiscal crisis), various forms of privatization organizations were created to fulfill that task. But because these organizations contained unavoidably inexperienced staff (since no one had any previous experience) and an untried - and often changing legal basis, state control was ineffective. Under such circumstances it was network capital again which was able to smooth the road towards successful privatization (Sik 1994b). Through relying on network capital one could pick out the valuable tit-bits from the immense herds of worthless stock, and one also needed network-capital to achieve state-capture; i.e., to set the process of privatization going - and let it run the way the buyer wanted: cheap prices and decisions made at the appropriate moments ${ }^{20}$.

\section{AND DEPENDENT WE REMAIN (NETWORK DEPENDENT PATH-DEPENDENCY MEETS THE WORLD)}

Let's suppose that the world we are approaching on a network-sensitive path is network-insensitive. This is probable even if there are convincing examples in all forms of capitalism demonstrating that the business networks cannot be left out of consideration, such as:

\footnotetext{
20 The part played by network-capital in privatisation is beautifully illustrated in a case study (Gyukits - Szántó 1998) in a nutshell: someone wants to privatise a hospital, but even though an important amount of network capital is invested does not reach his goal because the
} network capital of another competitor blocks the sale. 
- the lack of written contracts in the case of American capitalism (Macauley 1993);

- the diverse forms of clientele in the case of the four Asian tigers (Dore 1992);

- the global labor-market of managers and intellectuals (Dornstein 1977);

- the network-sensitivity of industrial districts (Piore - Sabel 1984);

- the self-reproducing small world of the German ownership system (Kogut -Walker 2001).

If this hypothesis is correct, then we must assume that the actors in a network-insensitive culture of globalization will be distrustful of a networksensitive post-communist reality.

However, the everyday experience of Hungarian network sensitivity can often be simultaneously attractive and unattractive to the individualistic and alienated "Westerner". Network capital may attract network-insensitive tourists and expatriates in the form of a long-missed form of hospitality or openness, but at the same the same people will be annoyed by the downside of the network sensitivity of everyday life (easy intrusion into their private spheres, gossiping, nepotism and favoritism):

"Rules are very important. [...] if I want something done that they don't want to do, they will say that what I want is simply impossible because of some regulation or other. But if they don't want to pay taxes, or want to drive into a one-way street, or park where it's prohibited, or drive faster than the limit, then they won't let themselves be bothered by regulations at all. When I first arrived here, I thought everything happened according to certain rules. But it's not the case. People have a lot of individual initiative and they only use rules to serve themselves. 'Oh, this is impossible, it's against the regulations'- means: 'I can't be bothered'. Maybe it's a polite form of saying: 'Are you crazy, this is out of question'. Instead, they say: 'It's against the rules'.'

(XY from the U.S.A in Juhasz 2000: 77)

"If you want something, the clerk to whom you present your claim will say what you want is impossible. So you start arguing. The clerk says it's maybe possible after all, but it's not a sure thing, he must ask somebody. The curtains are generally drawn at that point. The third step is when they start saying you can either do this or else that, the choice is up to you. The last step is when they act as if nobody ever 
expressed a doubt about the feasibility of what you want, the whole matter being the most natural thing in the world. In client-sensitive cultures like the U.S., all available information is put to your disposal so you can chose yourself among the alternatives. And people keep smiling at you all the time [...] Here, rules are pliable according to your own case. When Americans say 'no', they mean it. Here you can open an argument with officials...'

(AB from the U.S.A. in Juhász 2000: 67)

As the two examples show, we should assume conflicts when the networkinsensitive highway meets with the network-sensitive Hungarian path. It is most likely when a non-corrupt world meets with a world in which the culture of corruption is well-developed. The term "culture of corruption" means that:

"... there is practically no administrative procedure - as small as the matter may be - for which the official in charge does not ponder resorting to "alternative solutions" i.e., offering advantages or special treatment while at the same time hoping for some sort of service or gift in exchange, either before (to encourage) or after (to reciprocate) the transaction. ... Gifts, gratefulness cannot be left out of the game. Either because the time has come for the client to express gratitude and return the service or because both client and bureaucrat both know that "difficult matters" will present themselves anyway sooner or later, and it's advisable to secure the network in advance. A good example of this preventive securing is the case of the policemen in provincial towns who every day take in several hundreds of friendly greetings, hand-waves, nods and smiles from the drivers passing him by."

(Bíró 1998: 209-210)

The description cited above concerns Romania but it applies to presentday Hungary as well. The essence of this culture resides in a permanent readiness to build up networks, to invest into network capital, in the prompt use of existing network constantly manifested by all potential actors, in the constant maintenance of network-capital and regular analysis of the benefits drawn from the investments realized and in the "training" of all those around regarding how network-capital should (or should not) be used.

The constant fine-tuning of the techniques of corruption through the discussion and interpretation of corruption situations and the behavior of actors taking part in them is an important element of a network-sensitive 
culture. The examples below present three cases involving the three main bureaucracies an ordinary citizen depends on the most often: the welfare department, the local municipality, and the police. ${ }^{21}$

A: "We (at the welfare department E.S.) were working in turns with a colleague in the room at the end of the corridor, generally calling four or five people into the office where they could at least sit down. Those who had been employed by the same company usually preferred settling their affairs together; being in a group gave them a feeling of security. I remember exactly the day when I received my first shopping bag full of apricots, for I felt terribly embarrassed. The lady - who was suffering from severe backache because of the physical strain her job involved - carefully slipped the bag under my desk and answered my protest by asking me not to offend her by not accepting it for she had brought it gladly. I suddenly no longer knew what to do - accept it or refuse it. I was embarrassed at the thought of what the people waiting in the room might think and wondered whether they really would consider it a gesture of kindness, or rather as a gift you are supposed to give here in this office. I finally decided to accept it, for the contents of the bag weighed no more than a kilo and I felt I would really offend the lady if I refused it. Of course the whole situation was embarrassing for me, so I thought it would be best to close the matter quickly instead of hesitating. Before leaving, the lady wanted some feed-back about my realizing 'how bad her back was, how big her garden was and how hard it was to cultivate it... She would of course gladly work, but it would be so difficult for her to travel to her working place, not to speak of the fact that she could not manage a physically demanding job'. I would have taken these features into account even if I hadn't received anything from her, for I knew perfectly well that there were no jobs where she lived and that employers would be reluctant to take her because of the high costs that commuting would involve. The unemployment-benefit she got as former employee of the farmers' co-operative was the minimum amount, and I knew that people in her situation only got a minimal percentage back of the amount that had been deducted from their pay.

This attitude of course involuntarily started a process that finally became uncontrollable. The former employees of the farmers' co-operative always came together - what's more, they even gave the word to those made redundant after them that they should come to our room. Gifts became systematic: a little fruit or some vegetables never failed to appear on our desk. Meetings with them were always convivial: we discussed the agricultural situation, the expected quality

21 The case studies are the work of my students in human resource management (Sik 2002). 
of the forthcoming crop. The relationship that developed was characterized by a personal tone, trust, understanding and patience and I think, that the gifts they brought expressed their gratitude for the time we took for them and the attentive and fair treatment we gave them. But by accepting their gifts, we created the feeling that they only could hope for a human attitude through proceeding that way. This was perhaps especially the case for those who were waiting at another door and saw that people came into our office carrying parcels and departed without them. Of course we never kept those gifts for ourselves, never took them home, but put them out on the dining table for our colleagues to help themselves, thus avoiding eventually feel uncomfortable about them or creating misunderstandings. I shall add that the director of our branch alluded to what was the usual practice with gifts. He absolutely did not prohibit accepting small gifts that were not worth a large amount of money".

B: "My husband needed a new ID card. We called the information desk of the office and asked what forms, documents and bill stamps were needed. We got them all and filled them out; my husband took a day off work and went to the office with my mother-in-law early in the morning at opening time. Their turn came one and half-hours later. It then turned out that the birth certificate should not have been made more than three months before the date of presentation, and that that another copy should be obtained from the council of the district where my husband was born.

Of course nobody had told us these details on the phone. Now if my husband and my mother-in-law went to get the fresh copy at the other district council, they could at best hope to arrive back half an hour before closing time. Which meant that if the queuing time remained at one and half hours, then they had no chance of getting in that day. My mother-in-law immediately measured up the situation and addressed the clerk, asking for 'help'. She started a conversation with her. She asked whether they were always so many people waiting, whether the people were impatient, what was the new system like, whether they had more work than before, etc. Of course the clerk jumped on the occasion and started complaining. It wasn't their fault if the queues were so long, that there were so many impatient clients, that the computer software often froze, etc. Of course my mother-in-law was very "understanding" and "sympathetic" And she asked what they could do, for her son could not take another day off work, but couldn't travel with an invalid ID card either. She expressed how grateful she would be if they could settle the matter that day. The expression "very grateful" was of course duly stressed, which had its effect. The clerk wrote down her name and told them to ask for her at the door at their return, and said she would give them precedence. 
Luckily enough, they succeeded in obtaining a copy of the birth certificate and returning within opening hours. They bought some coffee and sweets in a supermarket on their way back. They mentioned the name of clerk at the door and were able to immediately proceed. The ID card would be delivered by mail within a month's time, she said, and gave my husband a letter of surety. At the end of the whole procedure, my mother-in-law gave her the shopping bag containing the coffee and sweets. It wasn't conspicuous as every clerk had an individual counter and the room was packed. The clerk said thank you and "you know, you shouldn't have, I would have done it anyway". But she then added, "Just keep a note of my name, I shall be glad to help anytime, just come and see me."

C: "The situation starts as follows: two young policemen on motorbikes motion the car (with a driver and his wife, and child on the back seat) which had just shot the traffic light, to pull aside. One remains with the motorbikes behind the car, the other addresses the driver. The policeman quickly explains the case, the degree of contravention of the regulations, the amount of the fine. Those seated in the car quietly wait for their fate to be decided, admitting their wrongdoing. The chauffeur, the son of a police lieutenant in a provincial city who has "grown up" to become an artist in the capital, remembers similar cases when his father was able to help him, and racks his brains, trying to imagine what his father would say he should do, how far the latter's hand might reach, but finally remains silent - maybe mostly thinking of the difficulties he will encounter to manage his everyday life without a driving license. The young policeman starts commenting on the danger to which the driver, as father and head of a family, has exposed his family, thus aggravating his case. Then the policeman repeats his point with an expression of worry on his face, apparently moved by a sincere desire to educate. He also remarks in the meantime that his colleague is already writing his report.

The cast changes from that moment on: the colleague at the back becomes the official representative, the documents of both car and driver are passed on to him; he is sitting on his motorbike with a severe expression on his face and an open notepad in his hand, writing and turning pages. The policeman by the car plays the role of the middleman. The official tone softens; he smiles to the child, and speaks with an increasing tone of understanding reproach to the offenders:

- Tell me sincerely: did you need this? What shall we do now? My colleague is already writing his report.

The young policeman comes and goes between car window and motorbike, repeating the sentence: 
- What shall we do now? What shall we do?

Those sitting in the car are slowly emboldened by his uncertainty: Why is he walking back and forth like that? What's taking them so long to settle the matter? It becomes clear that "the case could be arranged". The only question remaining open is that of the modality. The driver prudently starts inquiring after another conversational turn:

- Well, if you were not a policeman... then we could say... - the face of the young policeman remains passive, then he continues the sentence with an expressionless voice:

- As you like... two people can make a deal. ...

The documents wander back and the driver is asked to "put in whatever he thinks the deal is worth for him". The tone of the middleman policeman, in the meantime, has become confidential; "he feels relieved that we understand at last". He goes back to his colleague, so that the chauffeur must bring them his ID card, which the policeman has turned upside-down over the motor-bike bag, emptying the money into it so as not to touch it. We get our documents back and they let us go our way."

Of course, as demonstrated by the example below, post-communist proneness to corruption does not seem to cause much trouble to the directors of multinational companies:

"The actors of the story: the regional director of a multinational enterprise (Mr. X), his superior, the director of the marketing department; the head of a student organization of a college (Mr. Y) and the latter's wife, the director of the dorm of the college. It was the task of Mr. Y to organize cultural programs and to find sponsors. In case of successes he received $15 \%$ as commission. Mr. X and Mr. Y had maintained a friendly networking relationship for a couple of years. They got in touch with each other two or three times a year, as this was the number of programs held by the school for which sponsoring money was raised.

At the time of entrance exams to the college, Mr. X called Mr. Y. He said that the son of his boss, the director of the marketing department - and, as such, omnipotent master of all decisions made in the domain of sponsoring - had not been admitted to the dorm, a problem that "he wanted to solve in some way or other". He also said that if Mr. Y were willing to help - with the help of his wife - then they would not have to go begging from door to door to raise the money necessary for the school-programs anymore. Mr. Y was not particularly surprised by the request. It wasn't the first time he had been confronted with such a situation, and he did not dismiss the case; he merely said he would see what he could do, and let Mr. X know. He made enquiries and found out that the director of the college could decide about the admittance 
of 20 people. Neither Mr. Y nor his wife ever asked him to admit someone. Mrs. Y interceded for the son of Mr. X's boss, but her request was refused. Nevertheless, one of the 20 students in question retracted their request, so the boss' son was finally admitted. [...] So Mr. Y called the regional director and informed him that he finally had found a way of arranging a solution - at the price of much effort and persuasion - and that the boss' son would soon receive a letter officially informing him of his admission. Mr. X was awfully grateful and promised that the school could count on their support for the next program on the agenda. He kept his word, for in the following October, the company participated to organizing the program with goods (products, promotional articles, decorations, etc.) worth HUF 200000 (five times the amount of the former funding)." (Sik 2002)

Of course the conflict between the network-sensitive path and the networkinsensitive global world is always at its sharpest when the Hungarian corruption-based world confronts the corruption-free outer world not as business partner, but as competitor moved by opposing interests. If a Hungarian enterprise wants to oust a foreign competitor, the latter may very well come up with the argument that the Hungarian competitor is not playing fair because he uses corruption.

"The local rules of the game are labeled "corrupt", which means that
the economic expansion of the "strong dogs" is considered legitimate,
and what's more, morally justifiable, so they not only prove to be
better at competing but also acquire the moral upper hand. They may
therefore not only show off through their capital value, but also their
"cleanliness"; what's more, they are playing the part of the new "world
broom" - clearing away the local "rubbish dump" of corruption."

(Szilágyi 1998: 258)

The opposition between the network-sensitive post-communist world and the network- insensitive global world is made even sharper by international institutions capitalizing on the global fight against corruption. The name of the core institution in question is Transparency International (TI). The goals of this institution are to fight corruption at a world wide scale. The fact that the World Bank, the OECD, the UNO, the WTO and the Open Institute have joined the anti-corruption crusade of the TI is another sign of the global revaluation of corruption, but:

"The declarations, and resolutions, the committees and international conferences focusing on that subject are countless, such as, for 
instance, the International Anti-Corruption Conference sitting last year for the eighth time in Lima. The so-called Lima Declaration that came into being during that conference intends nothing less than to have all governments world-wide, all existing international, local and regional political, professional and civil organizations, all multilateral and bilateral humanitarian aid organisms, as well as all main organisms of global economy line up in the fight against corruption... What happened here? Has the world suddenly become so bad? Or was it already perverted, but nobody noticed until now? Or is it that some have recently acquired the power to change the state of things along their interests?"

(Gombár 1998: 50).

According to Gombár, the point is not that the economy, the arts, communication/media, and crime are global but that basic social processes are determined by supra-national organisms. The same is true for corruption, itself globalized, while remaining at the same time "local". Global corruption may confront its forefather, local corruption, but it also may use it, while the antidote to global corruption may only be global, for it is driven by much more powerful means than nation-states; but there exists no such global antidote, just as there exists no universal law or moral, and no world-police.

Is there any chance for the network capital dependent path-dependent post-communist culture to stop being corrupt? The answer is: not much. For then we should believe (and convince each other) that renouncing corruption will not deteriorate the smooth working of such economies and would not increase the power of global competitors on the market. Why should a citizen dispose of the well-tested and fine-tuned network capital investment in the form of gratitude money into a selected group of physicians in the hope or belief that he will be appropriately cared for without it? Or why should an entrepreneur dispose of the network capital invested into the tax authorities, the environmental supervision organism and/or the representatives of the hundreds of other supervisory organisms, hoping that from now on they will do their job honestly? This would be rational only if one could believe that both markets and states will turn into perfect markets and/or states without failure from one day to the next.

The ultimate question is whether a network-sensitive country can or cannot leave its path. Transforming this question into three simpler ones (thereby expressing the cultural, economic, and institutional aspect of the original question): Can a deeply socialized networking culture be abandoned? Can economic actors who have vested interests in maintaining corruptive networks 
be encouraged to forego these assets? Can institutions embedded in a networksensitive environment be disembedded from it?

My tentative answer is no, no, and no, respectively. The explanation follows the convincing arguments of Gerschenkron (1962) on the institution-specific nature of economic backwardness. I assume that just as the state substituted colonial wealth and a developed banking system in the process of "original accumulation of capital" in backward economies, network capital plays the same role in the course of the post-communist transformation. This is the only resource these economies have in plenty - consequently they cannot afford not to use it. And since it is very unlikely that the post-communist countries will ever reach the stage of economic development in which they can afford to rely less on network capital, the network dependent path will survive.

The good news is, however, that there are signs that the global world is getting more and more network-sensitive. I can envision the coming into being of a more network-sensitive era (due to various factors such as the spread of global bureaucracies and of trasnationalism, and due to the spread of world wide web, etc.), and consequently the post-communist network dependent path may differ less and less from the highway.

\section{REFERENCES}

Albert, Fruzsina - Bea Dávid (1998), “A barátokról [On friends]”, in, Kolosi, T. I. Gy,Tóth - Gy. Vukovich eds., Társadalmi Riport [Social Report], Budapest, TÁRKI, pp. 257-278.

Altmann, Yochannan (1990), "The role of personal social support networks in soviet type centralized command economies", Manuscript, Cranfield

Angelusz, Róbert - Róbert Tardos (1988), “A magyarországi kapcsolathálózatok néhánysajátossága [Some characteristics of the Hungarian social networks]", Szociológiai Szemle Vol. 2, pp. 185-204.

Angelusz, Róbert - Róbert Tardos (1998), “A kapcsolathálózati erőforrások átrendeződésének tendenciái a kilencvenes években [Tendencies of restructuring of the network resources in the nineties]", in: Kolosi, T. - I. Gy. Tóth - Gy. Vukovich, eds., Társadalmi Riport [Social Report], Budapest, TÁRKI, pp. 237-254.

Arthur, Brian W. (1988), "Self Reinforcing Mechanisms in Economics", in: Anderson, Philip W. - Kenneth J. Arrow, - David Pines. eds., The Economy as an Evolving Complex System, Reading, Mass.: Addison-Wesley

Berliner, Joseph (1957), Factory and Manager in the U.S.S.R., Books on Demand

Bíró, A. Zoltán (1998), "Mindennapi ellenfelünk, a rend [Order: our daily enemy]", in: Gombár, Csaba - Elemér Hankiss - László Lengyel, Írások a korrupcióról [Writings on corruption], Budapest, Helikon-Korridor, pp. 209-224.

Christakis, Nicholas A. - James Fowler (2009), Connected: The Surprising Power of 
Our Social Networks and How They Shape Our Lives, Little, Brown Co.

Clarke, Simon (2000), "The Closure of the Russian Labour Market", European Societies Vol. 2, No. 4, pp. 483-504.

Czakó, Ágnes - Endre Sik (1988)," Managers' Reciprocal Transactions", Connections Vol. XI, No. 3, pp. 23-32.

Czakó, Ágnes - Endre Sik (1995), “The Role of Network as a Resource” in: Mendell, M. - Klaus Nielsen eds., Economic Transactions in a Post-Communism In Europe: Central and East, Black Rose Books, Montreal, pp. 224-247.

Dahrendorf, R (1990), Reflections on the revolution in Europe, New York, Random House

David, Paul (1985), "Clio and the Economics of QWERTY", American Economic Review No. 75, pp. 332-37.

Dore, Ronald (1992), "Goodwill and the Spirit of Market Capitalism", in Granovetter, Mark - Richard Swedberg eds., The Sociology of Economic Life, Westview Press, Boulder, pp.159-180.

Dornstein, Miriam (1977), "Some Imperfections in the Market Exchanges for Professional and Executive Services", The American Journal of Economics and Sociology April, Vol 36, Mo. 2, pp. 113-128.

Etzioni, Amitai (1991), "Eastern Europe: the Wealth of Lessons”, Challenge JulyAugust, pp. 4-10.

Fokasz, Nikosz (1999), "Balkán [Balcan]", Élet és Irodalom Vol. 9, No. 17, p. 8.

Gábor, R. I. (1994), “Modernity or a New Kind of Duality?”, in: Kovács, J. Mátyás ed., Transition to Capitalism? Transaction Publ., New Brunswick, pp. 3-20.

Gerschenkron, Alexander (1962), Economic Backwardness in Historical Perspective, Cambridge, The Belknap Press of Harvard University Press

Gombár, Csaba (1998), “A korrupció mint közrossz [Corruption as common evil]”, in: Gombár, Csaba - Elemér Hankiss - László Lengyel, Írások a korrupcióról [Writings on corruption], Budapest, Helikon-Korridor, pp. 47-87.

Gyukits, György - Zoltán Szántó (1998), "Privatizáció és társadalmi tőke [Privatization and social capital]", Szociológiai Szemle No.3, pp. 83-98.

Harcsa, István-János Bocz (2001), “Az anyagi és nem-anyagi támogatások együttes átalakulása [Joint transforming of financial and non-financial supports]", in: $A$ háztartások közötti együttmüködés jellemzöi [Characteristics of co-operations between households], Budapest, KSH, pp. 14-18.

Héthy, Lajos-Csaba Makó (1972), Munkásmagatartások és a gazdasági szervezet [Worker behaviors and economical organization], Budapest, Akadémiai

Juhász, Veronika (2000), “Amerikaiak Budapesten az 1990-es évek végén [Americans in Budapest at the end of the 1990s]", in: Sik, Endre -Judit Tóth eds., Diskurzusok a vándorlásról [Discourses on migration], Budapest, Nemzetközi Migrációs és Menekültügyi Kutatások Központja, pp. 60-81.

Kogut, Bruce - Gordon Walker (2001), "The Small World of Germany and the Durability of National Networks", American Sociological Review Vol. 66, No. 3, pp. 317-335. 
Kuczi, Tibor - Csaba Makó (1997), "Towards Industrial Districts? Small Firm Networking in Hungary" in: Grabher, G. - D. Stark eds., Restructuring Networks in Post-Socialism (Legacies, Linkages and Localities), Oxford, Oxford University Press, pp. 176-189.

Ledeneva, Alena V. (1998), Russia's Economy of Favours, Cambridge, Cambridge University Press

Lonkila, Markku (1999), Social Networks in Post-Soviet Russia, Helsinki, Kikimora Publ.

Magyari-Vincze, Enikő - Margit Feischmidt (1994), “A CARITAS és a romániai átmenet [The CARITAS and the Romanian transforming]", Replika 15-16, pp. 6588 .

Macauley, Stewart (1992), "Non-contractual Relations in Business. A Preliminary Study", American Sociological Review, Vol. 28, pp.55-67.

Mars, Gerald - Yochanan Altman (1983). "The Cultural Bases of Soviet Georgia's Second Economy” Soviet Studies Vol. XXXV, No. 4, October 1983.

Miller, William L. - Ase Grodeland - Tatjana Koshechkina (1998), "Are the People Victims or Accomplices? The Use of Presents and Bribes to Influence Officials in Eastern Europe, OSI Local Governtment and Public Service Reform Intiative”, Discussion Paper, No. 6.

Mishler, William - Richard Rose (2001), "Political Support for Incomplete Democracies: Realist vs. Idealist Theories and Measures", International Political Science Review Vol. 22, No. 4, pp. 303-320.

North, C. Douglass (1990), Institutions, Institutional Change and Economic Performance, Cambridge, Cambridge University Press

North, C. Douglass (1994), "Economic Performance Through Time", The American Economic Review, Vol. 84, No. 3, pp. 359-368.

O’Brian, David J. - Valeri V. Patsiorkovski - Larry Dershem- Lylova Oksana (1996), "Social Capital and Adaptation to Social Change in Russian Villages", Studies in Public Policy No. 263, University of Strathclyde

Piore, Michael J. - Charles, F. Sabel (1984), Second Industrial Divide, Basic Books

Rose-Ackerman, Susan (2001), Trust, Honesty and Corruption, Prepared for the Workshop on Honesty and Trust in Post-Socialist Societies, Budapest, Collegium Budapest, May 25-26.

Rose, Richard - Christian Haerpfer (1992), "New democracies between State and Market", Studies in Public Policy No 204, University of Strathclyde

Sampson, Steven (n.d.) “A szóbeszéd szerepe a szocialista Romániában [The role of rumor in the socialist Romania]", Jel-Kép, pp. 59-77.

Sik, Endre (1988), "Reciprocal Exchange of Labour: the Hungarian Case", in: Ray, Pahl ed., On Work, Oxford-N.Y. Basil Blackwell, pp. 527-547.

Sik, Endre (1994a), "The Vulture and the Calamity or Why were Hungarian Taxi Drivers Able to Rebel Against increased Gasoline Prices?”, in: Kovács, János M., ed., Transition to Capitalism?, Transaction Publishers, London, New Brunswick, pp. 275-292.

Sik, Endre (1994b) "Network Capital in Capitalist, Communist, and Post-communist 
Societies", International Contributions to Labor Studies Vol. 4, pp. 73-93.

Sik, Endre (2002), "Mindennapi korrupcióink [Our daily corruptions]", Szociológiai Figyelö Vol. VI, No. 1-2, 131-145.

Sik, Endre (2006), “Tőke-e a kapcsolati tőke, s ha igen, mennyiben nem? [Is social capital a form of capital and if yes, in what extent it isn't?] "Szociológiai Szemle No. 2, pp. 72-95.

Stark, David (1995), "Not by design: The Myth of Designer Capitalism in Eastern Europe", in: Hausner, Jerzy - Bob Jessop - Klaus Nielsen eds., Strategic Choice and Path-dependency in Post-Socialism, Edward Elgar, Aldershot, pp. 67-83.

Stark, David (1996), "Recombinant Property in East European Capitalism", American Journal of Sociology Vol. 101, No. 4, pp. 993-1027.

Szilágyi, Ákos (1998), "KKK, avagy Oroszország elrablása [KKK, or robbery of Russia]", in: Gombár, Csaba - Elemér Hankiss - László Lengyel, Írások a korrupcióról [Writings on corruption], Budapest, Helikon-Korridor, pp. 256-313.

Tóth, Lilla (1999), "Vállalkozói kapcsolatok egy községben”, in: Lengyel, György, ed. Kisvállalkozások megszünése, bövülése és kapcsolatrendszere [Windup, expansion and network systems of small enterprises], Budapest, BKE, pp. 135-172.

Vedres, Balázs (2007), "Pathways from postsocialism: ownership sequence and performance of firms in Hungary, 1991-1999", European Management Review Vol. 4, No. 2, pp. 93-105.

Wilenski, R.H. (1963), Modern francia festök [Modern French Painters], Budapest, Corvina

Yakubovich, Valery - Irina Kozina (2000), "The Changing Significance of Ties", International Sociology Vol 13, No. 3, pp. 479-500. 